\title{
PENETAPAN TERSANGKA MENURUT HUKUM ACARA PIDANA DALAM PERSPEKTIF HAK ASASI MANUSIA
}

\author{
Bahran \\ Fakultas Syariah UIN Antasari, Jl. Ahmad Yani Km.4,5 Banjarmasin \\ e-Mail: bahranbasri@gmail.com
}

\begin{abstract}
Suspected suspect made by the police to a person suspected as a criminal act must be based on the provisions stipulated in the Law Number 8 of 1981 concerning the Criminal Procedure Code. The requirement to be presumed to be a suspect under this law is still blurry, thereby generating multi-interpretation. Then the Constitutional Court in its decision number 21 / PUU-XII / 2014 provides a more concrete interpretation of Article 1 points 14, Article 17 and Article 21 of the KUHAP which basically mentions that to set a suspect to a minimum must be fulfilled two means of evidence. However, the decision of the Constitutional Court does not limit the length of a person to the suspect's status, so that one may be a suspect forever. Such a condition would potentially have the potential for abuse of authority and the violation of human rights, so that this legal uncertainty is very detrimental to the basic rights of citizens for legal and fairness.
\end{abstract}

Keywords: Suspect, KUHAP, HAM, Legal Certainty, Justice.

Abstrak: Penetapan tersangka yang dilakukan oleh kepolisian kepada seseorang yang diduga sebagai pelaku tindak pidana harus berdasarkan ketentuan yang diatur dalam Undang Undang Nomor 8 Tahun 1981 tentang Hukum Acara Pidana. Persyaratan untuk dapat ditetapkan sebagai tersangka menurut undang undang ini dinilai masih kabur, sehingga menimbulkan multi interpretasi. Kemudian Mahkamah Konstitusi dalam putusannya bernomor 21/PUU-XII/2014 memberikan interpretasi yang lebih konkret terhadap Pasal 1 angka 14, Pasal 17 dan Pasal 21 KUHAP yang pada pokoknya menyebutkan bahwa untuk menetapkan tersangka kepada seseorang minimal harus dipenuhi dua alat bukti. Akan tetapi putusan Mahkamah Konstitusi ini tidak juga memberikan batasan lamanya seseorang menyandang status tersangka, sehingga bisa seseorang menjadi tersangka selamanya. Kondisi seperti ini tentu sangat berpotensi terjadinya penyalahgunaan wewenang dan pelanggaran terhadap HAM, sehingga ketidakpastian hukum ini sangat merugikan dan mencederai hak dasar warga negara untuk kepastian hukum dan keadilan.

Kata kunci : Tersangka, KUHAP, HAM, Kepastian Hukum, Keadilan.

\section{Pendahuluan}

Perubahan kedua Undang

Undang Dasar 1945 yang disahkan pada

tanggal 18 Agustus 2000 memberikan

kometmen yang kuat terhadap penegakan hukum dan perlindungan terhadap hak asasi manusia. Pasal 28D

Undang Undang Dasar 1945 menyebutkan bahwa "Setiap orang

DOI: http://dx.doi.org/10.18592/sy.v17i2.1972 
berhak atas pengakuan, jaminan, perlindungan, dan kepastian hukum yang adil serta perlakuan yang sama dihadapan hukum". Kepastian hukum yang adil merupakan hak setiap orang yang sangat berarti dan harus dipenuhi ketika berhadapan dengan proses hukum, karena hanya dengan cara yang demikian itu orang akan percaya terhadap hukum itu sendiri.

Berkaitan dengan kepastian hukum menuju tujuan hukum itu sendiri yaitu keadilan, kita teringat kepada seorang filosof hukum yang terkemuka yaitu Gustav Radbruch yang juga seorang legal scholar dari Jerman yang mengajarkan konsep tiga ide dasar hukum. Menurut Gustav Radbruch, hukum harus mengandung 3 (tiga) nilai identitas, yaitu sebagai berikut ${ }^{1}$

1. Asas kepastian hukum (rechtmatigheid). Asas ini meninjau dari sudut yuridis.

2. Asas keadilan hukum (gerectigheit). Asas ini meninjau dari sudut filosofis, dimana keadilan adalah kesamaan hak untuk semua orang di depan pengadilan

1 Dwika, "Keadilan dari Dimensi Sistem Hukum", http://hukum.kompasiana.com. (02/04/2011), diakses pada 24 Juli 2014.
3. Asas kemanfaatan hukum (zwechmatigheid atau doelmatigheid atau utility.

Harus diakui memang terjadi perdebatan dikalangan ahli hukum berkaitan dengan pertanyaan bahwa yang mana yang harus diutamakan, apakah asas kepastian hukum, baru keadilan dan kemudian baru kemanfaatan hukum. Benturan kepentingan terkadang sulit untuk mengabil sebuah keputusan ketika dihadapkan kepada persoalan yang konkret, karena antara kepastian hukum, keadilan hukum dan kemanfaatan hukum tidak berjalan pada satu arah yang sama. Ketika sampai pada pilihan lebih mengutamakan kepastian hukum, tidak jarang harus mengorbankan keadilan dan kemanfaatannya. Bagitu juga kalau lebih memilih keadilan yang ingin dicapai, maka tidak jarang juga harus mengorbankan kepastian hukum dan kemanfaatannya. Demikian juga ketika harus memilih kemanfaatannya, maka terkadang dengan mengorbankan kepastian dan keadilan hukum. Bagaiman cara agar supaya ketiga asas tersebut yaitu kepastian hukum, keadilan dan kemanfaatan hukum dapat berjalan bersama-sama, maka perlu

DOI: http://dx.doi.org/10.18592/sy.v17i2.1972

http://jurnal.uin-antasari.ac.id/index.php/syariah/article/view/1972 
upaya cerdas dalam memahami dan memberikan makna kepada hukum itu sendiri.

Walaupun terjadi perbedaan pendapat dikalangan ahli hukum, paling tidak ada dua kelompok yang memberikan pandangannya, yaitu kelompok positivisme dan kelompok fungsionalis. Bagi kelompok positivisme lebih menekankan kepada kepastian hukum, sedangkan kelompok fungsionalis lebih menekankan kepada kemanfaatan hukum. Jika hanya mengacu kepada pandangan kedua kelompok tersebut, lalu dimana posisi keadilan hukum, pada hal inti dari hukum itu secara filosofis adalah keadilan.

Menurut Utrecht, kepastian hukum mengandung dua pengertian, yaitu pertama, adanya aturan yang bersifat umum membuat individu mengetahui perbuatan apa yang boleh atau tidak boleh dilakukan, dan kedua, berupa keamanan hukum bagi individu dari kesewenangan pemerintah karena dengan adanya aturan yang bersifat umum itu individu dapat mengetahui apa saja yang boleh dibebankan atau dilakukan oleh Negara terhadap individu. $^{2}$

Ajaran kepastian hukum ini berasal dari ajaran yuridis-dogmatik yang didasarkan pada aliran pemikiran positivistis di dunia hukum, yang cenderung melihat hukum sebagai sesuatu yang otonom, yang mandiri, karena bagi penganut pemikiran ini, hukum tak lain hanya kumpulan aturan. Bagi penganut aliran ini, tujuan hukum tidak lain dari sekedar menjamin terwujudnya kepastian hukum. Kepastian hukum itu diwujudkan oleh hukum dengan sifatnya yang hanya membuat suatu aturan hukum yang bersifat umum. Sifat umum dari aturanaturan hukum membuktikan bahwa hukum tidak bertujuan untuk mewujudkan keadilan atau kemanfaatan, melainkan semata-mata untuk kepastian. $^{3}$

Hukum terkadang dirasakan sangat keras, berlaku bagia siapa saja dan kapan saja dan bahkan dapat melukai perasan yang sangat dalam, akan tetapi hal yang demikian dapat

${ }^{2}$ Riduan Syahrani, Rangkuman Intisari Ilmu Hukum, Penerbit Citra Aditya Bakti,Bandung, 1999, hlm.23.

3 Achmad Ali, Menguak Tabir Hukum (Suatu Kajian Filosofis dan Sosiologis), Penerbit Toko Gunung Agung, Jakarta, 2002, hlm.82-83. 
ditolong dengan sebuah kelembutan yaitu keadilan. Walaupun harus disadari bahwa keadilan bukanlah satu-satunya tujuan hukum, akan tetapi tujuan hukum yang sesungguhnya atau yang paling substantif adalah keadilan itu sendiri. Jika hal ini sudah dipahami, maka penegakan hukum harus berintikan keadilan dengan memperhatikan asas kepastian hukum dan asas kemanfaatan hukum. Sebagaimana telah dijelaskan bahwa dalam melaksanakan ketiga tujuan hukum ini tentu dengan menggunakan "asas prioritas". Akan tetapi keadilan harus menempati posisi yang pertama dan utama dari pada kepastian dan kemanfaatan. Dari ketiga tujuan hukum tersebut tidak lah dapat dilaksanakan secara bersama karena sebagaimana diketahui, di dalam kenyataanya sering sekali antara kepastian hukum terjadi benturan dengan kemanfaatan, atau antara keadilan dengan kepastian hukum, antara keadilan terjadi benturan dengan kemanfaatan.

Sebuah permasalahan yang menarik untuk dikaji berkaitan dengan kepastian hukum adalah dalam hal proses penegakan hukum, hususnya dalam proses hukum acara pidana, dimana seseorang yang ditetapkan sebagai tersangka tidak diberikan batas waktu yang pasti kapan status tersangkanya itu berakhir. Hal ini tentu membawa konsekuensi hukum tersendiri bagi tersangka tersebut, karena walaupun secara yuridis belum ada kepastian dinyatakan bersalah, akan tetapi secara sosial orang tersebut sudah dianggap bersalah dan menanggung rasa malu di masyarakat. Bahkan dalam halhal tertentu, di satu sisi si tersangka tidak bisa menggunakan hak-hak hukumnya secara maksimal, sehingga dinilai sangat merugikan dan tidak memberikan rasa keadilan. Pada sisi yang lain, tidak pastinya kapan status tersangka itu akan berakhir sangat berpotensi terjadinya pelanggaran hak asasi manusia. Dari sudut penyidik, ketidakpastian hukum ini dapat dipergunakan untuk melakukan pemerasan terhadap tersangka dengan alasan agar perkaranya tidak diproses. Berdasarkan ketidakpastian hukum status tersangka tersebut diatas, dikaitkan dengan potensi pelanggaran hak asasi manusia dalam kerangka penegakan hukum hak asasi manusia, maka tulisan ini mencoba untuk menkaji secara normatif bagaimana status tersangka dalam perspektif Undang Undang Nomor 8 Tahun 1981 tentang 
Hukum Acara Pidana dan Undang Undang Nomor 39 Tahun 1999 tentang Hak Asasi Manusia.

\section{Penetapan Tersangka Menurut UU} No. 8 Tahun 1981.

\section{Berdasarkan ketentuan Pasal 1 angka 14 Undang Undang Nomor 8} Tahun 1981 tentang Hukum Acara Pidana (selanjutnya disebut KUHAP) menyebutkan bahwa "Tersangka adalah seorang yang karena perbuatannya atau keadaannya, berdasarkan bukti permulaan patut diduga sebagai pelaku tindak pidana". Pada tahapan ini seseorang ditetapkan sebagai tersangka hanya berdasarkan bukti permulaan yang didapat dari hasil penyelidikan yang dilakukan oleh kepolisian. Berdasarkan bukti permulaan ini kemudian seseorang patut diduga sebagai pelaku tindak pidana. Ketentuan ini menimbulkan multi tafsir, karena untuk menentukan sesuatu sebagai bukti permulaan itu sangat tergantung kepada kualitas dan siapa yang memberikan pengertian tersebut, antara penyidik dengan tersangka atau kuasa hukumnya sangat mungkin berbeda.

Keputusan penyidik untuk menetapkan seseorang sebagai tersangka merupakan tindak lanjut dari sebuah proses hukum penyelidikan yang dilakukan oleh kepolisian. Berdasarkan ketentuan Pasal 1 angka 5 KUHAP menyebutkan bahwa "Penyelidikan adalah serangkaian tindakan penyelidik untuk mencari dan menemukan suatu peristewa yang diduga sebagai tindak pidana guna menentukan dapat atau tidaknya dilakukan penyidikan menurut cara yang diatur dalam undang undang ini" Kriteria apa yang dipergunakan oleh penyelidik untuk menentukan bahwa suatu perbuatan merupakan suatu perbuatan pidana, sehingga dapat ditingkatkan ke proses hukum penyidikan. Untuk menjawab hal ini perlu kiranya seorang penyelidik mempunyai kemampuan untuk mengidentifikasi suatu perbuatan atau peristewa sebagai tindak pidana dengan menggunakan ilmu hukum pidana. Secara umum dapat dikemukakan disini bahwa yang dimaksud dengan tindak pidana adalah perbuatan yang dilarang untuk dilakukan atau mengabaikan suatu keharusan yang diwajibkan oleh undang undang, yang apabila di;lakukan atau diabaikan diancam dengan hukuman. Dari pengertian umum tindak pidana ini dapatlah diketahui bahwa setiap perbuatan yang dikwalifikasikan sebagai tindak pidana harus 
mengandung unsur melawan hukum, yaitu melanggar larangan undang undang atau mengabaikan suatu keharusan yang diwajibkan oleh undang undang, yang dilakukan dengan sengaja atau karena kealpaanya, atas pelanggarang tersebut diancam dengan pidana.

Jika hasil dari proses hukum penyelidikan berkesimpulan, penyelidik berkeyakinan bahwa perbuatan atau peristewa ini merupakan tindak pidana, maka proses hukum sudah barang tentu ditingkat ke proses hukum penyidikan. Berdasarkan ketentuan Pasal 1 angka 2 KUHAP menyebutkan bahwa "Penyidikan adalah serangkaian tindakan penyidik dalam hal dan menurut cara yang diatur dalam undang undang ini untuk mencari serta mengumpukan bukti yang terjadi dan guna menemukan tersangkanya". Ketentuan ini tidak memberikan penjelasan yang konkret apa dan bagaimana yang dimaksud serangkaian tindakan penyidik itu, sedangkan ketentuan Pasal 7 ayat (1) hanya memberikan kewenangan apabila proses hukum penyidikan dilakukan. Satu hal yang cukup menarik disini adalah kapan dapat dikatakan bahwa penyidikan telah dimulai. Jika dikaji ketentuan dalam
KUHAP, maka ternyata tidak ada satu pasalpun dalam KUHAP yang secara tegas memberikan penjelasannya. Ketetntuan Pasal 109 ayat (1) KUHAP menyebutkan bahwa "Dalam hal penyidik telah mulai melakukan penyidikan suatu peristewa yang merupakan tindak pidana, penyidik memberitahukan hal itu kepada Penuntut Umum" Ketetuan ini menjelaskan bahwa jika penyidik telah memulai penyidikan, maka hal ini harus diberitahukan kepada Penuntut Umum. Akan tetapi tidak memberikan penjelasan kapan mulainya, hanya disebutkan "telah mulai". Jawaban terhadap pertanyaan ini penting sekali bagi tersangka dalam rangka membela dan melindungi diri dari tindakan hukum yang tidak sah.

Sebelum dilakukan judicial review di Mahkamah Konstitusi, beberapa ketentuan di dalam KUHAP yang berkaitan dengan kwalitas dan kuantitas alat bukti sebagai dasar seseorang ditetapkan sebagai tersangka kurang memberikan kepastian hukum. Hal ini disebabkan karena kata-kata yang digunakan dalam redaksional KUHAP bersifat ambigu, sehingga menimbulkan penafsiran yang berbeda antara penyidik sebagai aparat penegak 
hukum dengan orang yang diduga sebagai pelaku tindak pidana.

Selama ini yang dipahami oleh masyarakat adalah bahwa jika seseorang ditetapkan sebagai tersangka yang diduga telah melakukan suatu tindak pidana, maka status tersangka tersebut sering menimbulkan ketidak-pastian hukum, hal ini lebih disebabkan karena ketiadaan batas waktu yang diberikan oleh aparat penegak hukum berapa lama seseorang yang diduga telah melakukan tindak pidana tersebut menyandang status sebagai tersangka atau kapan status tersangka yang disandangnya itu selesai. Hal ini tentu sangat berpeluang menimbulkan ketidak-adilan, sebab bisa saja selama penyidikan berlangsung kondisi ini dimanfaatkan sebagai alat untuk melakukan kriminalisasi. Terlalu lama menyandang status tersangka tanpa dibaringi kemajuan yang berarti dalam proses hukum penyidikan, apalagi kalau belum cukup bukti sehingga proses hukum di diamkan saja tanpa ada kepastian kapan tindak lanjutnya, maka sama halnya dengan memasung kebebasan orang. Hal ini pernah dialami oleh mantan Direktur Bina Medik Pelayanan Kemenkes Ratna Dewi Umar yang menyandang status tersangka cukup lama. Ratna Dewi Umar selama
2,5 tahun ditetapkan sebagai tersangka kasus pengadan alat kesehatan di Depkes tahun 2006. Hal ini menunjukan bahwa jika tidak ada aturan dalam undang undang yang membatasi batas waktu status tersangkan seseorang, maka sangat mungkin membuat orang yang ditetapkan sebagai tersangka tersebut bisa menjadi tersangka abadi.

Mahkamah Konstitusi dalam putusannya bernomor 21/PUUXII/2014 yang mengabulkan sebagian permohonan terpidana korupsi kasus proyek biomediasi PT. Chevron Bachtiar Abdul Fatah yang salah satunya menguji ketentuan objek praperadilan yang menjadi polemik terutama pasca putusan praperadilan PN Jakarta Selatan yang membatalkan status tersangka Komjen (Pol) Budi Gunawan oleh KPK. Mahkamah Konstitusi menyatakan inkonstitusional bersyarat terhadap frasa "bukti permulaan", "bukti permulaan yang cukup", dan "bukti yang cukup" dalam Pasal 1 angka 14, Pasal 17, dan Pasal 21 ayat (1) KUHAP sepanjang dimaknai minimal dua alat bukti sesuai Pasal 184 KUHAP. Pasal 77 huruf a KUHAP dinyatakan inkontitusional bersyarat sepanjang dimaknai termasuk penetapan 
tersangka, penggeledahan, dan penyitaan. Putusan Mahkamah

Konstitusi ini hanya menetapkan bahwa frasa "bukti permulaan", "bukti permulaan yang cukup", dan "bukti yang cukup" dalam Pasal 1 angka 14, Pasal 17, dan Pasal 21 ayat (1) KUHAP sepanjang dimaknai minimal dua alat bukti sesuai Pasal 184 KUHAP dan menambah objek praperadilan, yaitu penetapan tersangka, penggeledahan, dan penyitaan. Mahkamah beralasan KUHAP tidak memberi penjelasan mengenai batasan jumlah (alat bukti) dari frasa "bukti permulaan", "bukti permulaan yang cukup", dan "bukti yang cukup". Mahkamah menganggap syarat minimum dua alat bukti dan pemeriksaan calon tersangka untuk transparansi dan perlindungan hak asasi seseorang agar sebelum seseorang ditetapkan sebagai tersangka telah dapat memberi keterangan secara seimbang. Hal ini menghindari adanya tindakan sewenang-wenang oleh penyidik terutama dalam menentukan bukti permulaan yang cukup itu. Sementara dalam pranata praperadilan, meski dibatasi secara limitatif dalam Pasal 1 angka 10 jo Pasal 77 huruf a KUHAP. Namun, penetapan tersangka adalah bagian dari proses penyidikan yang terbuka kemungkinan terdapat tindakan sewenang-wenang oleh penyidik yang termasuk perampasan hak asasi seseorang. Memang Pasal 1 angka 2 KUHAP kalau diterapkan secara benar tidak diperlukan pranata praperadilan. Namun, bagaimana kalau ada yang salah dalam menetapkan seseorang menjadi tersangka, sehingga sudah seharusnya penetapan tersangka menjadi bagian dari proses penyidikan yang dapat dimintakan perlindungan melalui pranata praperadilan.

Jika dilihat kebelakang sejarah pada saat KUHAP dibuat dan diberlakukan pada tahun 1981, saat itu penetapan tersangka belum menjadi isu krusial dan problematik dalam kehidupan masarakat Indonesia pada umumnya. Pada masa itu upaya paksa secara konvensional hanya dipahami sebatas pada penangkapan, penahanan, penyidikan dan penuntutan. Seiring dengan perkembangan meningkatnya kesadaran hukum masyarakat pada saat sekarang ini, bentuk upaya paksa telah mengalami berbagai perkembangan atau modifikasi yang salah satu bentuknya adalah "penetapan tersangka oleh penyidik" yang dilakukan oleh negara dalam bentuk label atau status tersangka pada seseorang yang diduga telah 
melakukan tindak pidana, tanpa ada batas waktu yang jelas, sehingga orang yang diduga telah melakukan tindak pidana tersebut dipaksa oleh negara untuk menerima status tersangka tanpa tersedianya kesempatan baginya untuk melakukan upaya hukum untuk menguji secara kualitas, legalitas dan kemurnian tujuan dari penetapan tersangka tersebut.

Kalau demikian pertanyaanya adalah berapa lama orang dapat berstatus sebagai tersangka, jawaban terhadap pertanyaan ini sangat tergantung pada beberapa hal diantaranya adalah berapa lama proses penyidikan yang dilakukan oleh penyidik, kemudian berkaitan dengan diterbitkannya SP3.

Sebagaimana telah dijelaskan diatas bahwa penyidikan adalah serangkaian tindakan penyidik dalam hal dan menurut cara yang diatur dalam undang undang KUHAP untuk mencari serta mengumpulkan bukti yang terjadi dan guna menemukan tersangkanya. Pertanyaanya adalah kapan mulai penyidikan itu? Dimulainya penyidikan itu ditandai secara formal prosedural dengan dikeluarkannya "Surat Perintah Penyidikan" oleh pejabat yang berwenang di instansi penyidik. Bagi pimpinan kepolisian dan kejaksaan, surat perintah penyidikan merupakan alat pengaman yang sangat efektif untuk mencegah terjadinya penyalahgunaan wewenang. Sebaliknya dipihak tersangka berarti ada jaminan kepastian hukum dan perlindungan hak asasi manusia. Bagi tersangka yang merasa penyidikan yang dilakukan terhadap dirinya tidak dilakukan berdasarkan surat perintah yang sah, dapat melakukan upaya hukum. Dalam surat perintah penyidikan ini juga tidak disebutkan berapa lama masa penyidikan dimaksud. Kembali kepada ketetntuan Pasal 109 ayat (1) KUHAP yang menyebutkan bahwa "Dalam hal penyidik telah mulai melakukan penyidikan suatu peristewa yang merupakan tindak pidana, penyidik memberitahukan hal itu kepada Penuntut Umum" Sebagaimana yang telah dijelaskan bahwa ketentuan pasal ini pun tidak memberikan batas waktu penyampaian pemberitahuan dimulainya penyidikan tersebut kepada penuntut umum.

Pemberitahuan ini merupakan kewajiban hukum penyidik, oleh karena itu harus dilakukan dengan segera dalam arti waktu yang sesingkat-singkatnya setelah dimulainya pemeriksaan 
tersangka. Akan tetapi hal inipun tidak memberikan waktu yang pasti. Oleh karena itu pengertian "segera" harus diartikan dalam waktu yang wajar. Bagaimana "waktu yang wajar" itu. Hal ini sangat tergantung kepada situasi dan kondisi dilihat dari segi kompleksitas, sikap penyidik yang langsung menangani perkara pidana yang bersangkutan dengan tidak mengulurulur waktu.

Kemudian jika dibaca ketentuan Pasal 139 KUHAP yang menyebutkan "Setelah Penuntut Umum menerima atau menerima kembali hasil penyidikan yang lengkap dari penyidik, ia segera menentukan apakah berkas perkara itu sudah memenuhi persyaratan untuk dapat atau tidak dilimpahkan ke pengadilan".

Dalam ketentuan pasal ini tidak disebutkan alokasi waktu yang diperlukan untuk menentukan sikap bagi penuntut umum, apakah perkara ini memenuhi syarat untuk dilimpahkan ke pengadilan atau tidak. Disini hanya disebutkan dengan kata "segera", hal ini berarti tidak ada memberikan kepastian hukum. Penelitian terhadap persyaratan kelengkapan berkas perkara bisa dilakukan secara cepat bagi perkaraperkara pidana yang pembuktiannya dianggap mudah, sebaliknya bagi perkara pidana yang pembuktiannya dianggap sulit dan alat buktinya baik secara kuantitas maupun secara kualitas kurang, maka dengan prinsip kehatihatian tentu waktu yang dibutuhkan relatif lama.

Mungkin inilah alasan mengapa KUHAP tidak menentukan waktu yang pasti, sehingga hanya menggunakan kata "segera". Akan tetapi yang menjadi persoalan adalah akibat ketidak-pastian ini berdampak pada ketidak-pastian seseorang menyandang status tersangka. Bisa saja terjadi berkas perkara pidana dari penyidik yang diterima oleh penuntut umum, dikembalikan lagi kepada penyidik dengan alasan tidak lengkap persyaratannya, baik persyaratan formil maupun persyaratan materil. Keadaan seperti ini bisa berulang-ulang, dalam arti berkas perkara pidana tersebut bolak-balik antara penyidik kepolisian dan penuntut umum.

Pemberitahuan dimulainya penyidikan oleh kepolisian kepada penuntut umum seyogyanya harus dimaknai sebagai kontrol negara yang dilakukan oleh penuntut umum terhadap penyidik kepolisian, akan tetapi KUHAP tidak memberikan 
sampai sejauh mana kontrol itu bisa dilaksanakan. Misalnya, penyidik kepolisian telah mulai melakukan proses penyidikan terhadap suatu tindak pidana dan tersangkanya sudah ditetapkan.

\section{Kemudian berdasarkan}

ketentuan Pasal 109 ayat (1) KUHAP, penyidik memberitahukan dimulainya penyidikan tersebut kepada penuntut umum. Akan tetapi setelah sekian lama menunggu, penuntut umum belum juga menerima pelimpahan perkara tersebut. Bahkan penuntut umum menanyakan kepada penyidik kapan perkara tersebut dilimpahkan, ternyata tidak mendapat jawaban yang memuaskan. Dalam kondisi seperti ini, bisakah penuntut umum memaksa penyidik kepolisian untuk segera melimpahkan perkara tersebut. Ternyata KUHAP tidak ada mengatur tentang hal ini, oleh karena itu penuntut umum tidak dapat memaksa penyidik kepolisian untuk segera melimpahkan suatu perkara pidana.

Dengan demikian, maka apabila penyidik telah menyampaikan pemberitahuan dimulainya penyidikan, kemudian tidak dilanjutkan dengan penyerahan berkas perkara atau pemberitahuan penghentian penyidikan, maka secara yuridis penyidikan itu belum selesai, artinya status tersangka yang telah ditetapkan kepada seseorang masih melekat padanya. Pengecualian dapat terjadi jika penyidik secara resmi menghentikan penyidikan itu sebagaimana disebutkan dalam ketentuan Pasal 109 ayat (2) bahwa "Dalam hal penyidik menghentikan penyidikan karena tidak terdapat cukup bukti atau peristewa tersebut ternyata bukan merupakan tindak pidana atau penyidikan dihentikan demi hukum, maka penyidik memberitahukan hal itu kepada penuntut umum, tersangka atau keluarganya". Kemudian menurut ketentuan Pasal 76 Peraturan Kapolri No. 14 Tahun 2012 tentang Manajemen Penyidikan Perkara Pidana menyebutkan bahwa penghentian penyidikan dilakukan apabila :

a. Tidak terdapat cukup bukti.

b. Peristewa tersebut bukan merupakan tindak pidana.

c. Demi hukum :

1. Tersangka meninggal dunia.

2. Perkara telah kedaluarsa.

3. Tindak pidana tersebut telah memperoleh putusan hakim yang mempunyai kekuatan hukum tetap (nebis in idem). Sebelum sampai pada kesimpulan untuk menghentikan penyidikan, biasanya dilakukan gelar 
perkara terlebih dahulu. Gelar perkara pada tahap akhir penyidikan ini bertujuan, diantaranya adalah untuk evaluasi proses penyidikan yang telah dilaksanakan, pemecahan masalah atau hambatan penyidikan, menentukan layak tidaknya berkas perkara dilimpahkan kepada penuntut umum atau dihentikan. Jika dalam gelar perkara diputuskan bahwa berkas perkara pidana tersebut tidak layak untuk dilimpahkan ke penuntut umum atau harus dihentikan, maka penyidik wajib mengirimkan Surat Pemberitahuan Penghentian Penyidikan (disingkat SP3) kepada pelapor, JPU dan tersangka atau penasihat hukumnya. Apabila SP3 sudah diterima oleh tersangka, maka dengan sendirinya status tersangkanya secara yuridis sudah berakhir. Sebaliknya jika penyidik tidak menerbitkan SP3, maka status tersangka tetap melekat, artinya belum berakhir.

\section{Penetapan Tersangka Dalam Perspektif Hak Asasi Manusia}

Dapatlah dikatakan bahwa hak asasi manusia merupakan hak-hak dasar yang sudah dipunyai oleh seseorang sejak ia masih dalam kandungan, sebagai pemberian sang pencipta Allah swt. sehingga hak asasi manusia seyogyanya dapat berlaku secara universal. Hak asasi manusia bukanlah pemberian pemerintah atau penguasa, oleh karena itu kebijakan apapun yang diambil sebagai regulator tidak boleh bertentangan dengan hak asasi manusia tersebut. Pemerintah atau penguasa hanya berwenang untuk mengatur agar supaya pelaksanaan hak asasi manusia berjalan secara efektif dan tidak saling berbenturan antara hak asasi manusia yang satu dengan yang lainnya.

Sejarah panjang memperjuangkan hak asasi manusia sudah dimulai sejak dulu kala, sebutlah Inggris sering disebut-sebut sebagai negara pertama di dunia yang memperjuangkan hak asasi manusia. Hal ini berdasarkan berbagai dokumen kenegaraan yang berhasil disusun dan disahkan, seperti Magna Charta. Sebagaiman diketahui bahwa pada awal abad XII Raja Richard yang dikenal adil dan bijaksana telah diganti oleh Raja John Lackland yang bertindak sewenang-wenang terhadap rakyat dan para bangsawan. Tindakan sewenangwenang Raja John tersebut mengakibatkan rasa tidak puas dari para bangsawan yang akhirnya berhasil mengajak Raja John untuk membuat suatu perjanjian yang disebut Magna 
Charta atau Piagam Agung yang dicetuskan pada tanggal 15 Juni 1215. Adapun isi prinsip dasar magna charta adalah pembatasan kekuasaan raja dan hak asasi manusia lebih penting dari pada kedaulatan raja. Dengan demikian maka tidak seorangpun dari warga negara dapat ditahan atau dirampas harta kekayaannya atau diasingkan atau dengan cara apapun dirampas hakhaknya, kecuali berdasarkan atas hukum. Disinilah mulainya perlindungan terhadap hak asasi manusia, karena hukum dan undangundang derajatnya lebih tinggi daripada kekuasaan raja saat itu. Ada beberapa poin penting isi magna charta yang relevan dengan tulisan ini diantaranya adalah :

1. Bahwa polisi ataupun jaksa tidak dapat menuntut seseorang tanpa bukti dan saksi yang sah.

2. Bahwa apabila seseorang tanpa perlindungan hukum sudah terlanjur ditahan, raja berjanji akan mengoreksi kesalahannya.

3. Bahwa seseorang yang bukan budak tidak akan ditahan, ditangkap, dinyatakan bersalah tanpa perlindungan negara dan tanpa alasan hukum sebagai dasar tindakannya ${ }^{4}$

Kemudia banyak pertanyaanpertanyaan yang berkaitan dengan hakhak rakyat dan jaminan-jaminannya, yang diajukan oleh kaum bangsawan kepada raja di depan parlemen pada tahun 1628 yang dimuat dalam petition of righats, diantaranya adalah :

a. Bahwa tentara tidak boleh menggunakan hukum perang dalam keadaan damai.

b. Bahwa pajak dan pungutan istimewa harus disertai persetujuan.

c. Bahwa warga negara tidak boleh dipaksanakan menerima tentara di rumahnya. 5

Kemudian Hobeas Corpus Act adalah undang- undang yang mengatur tentang penahanan seseorang, dibuat pada tahun 1679 yang berisi antara lain :

a. Bahwa seseorang yang ditahan segera diperiksa dalam waktu 2 hari setelah penahanan.

\section{4}

http:// wnw.informasiabli.com/2016/04/pi agam-magna-charta-tahun-1215.html 5 https:/ / brainly.co.id/tugas/801601 
b. Bahwa alasan penahanan seseorang harus disertai bukti yang sah menurut hukum.

Selain itu Bill of Rights juga merupakan undang-undang yang dicetuskan tahun 1689 dan diterima oleh parlemen Inggris, yang isinya mengatur antara lain

a. Bahwa parlemen berhak untuk mengubah keputusan raja.

b. Bahwa kebebasan berbicara dan mengeluarkan pendapat.

c. Bahwa kebebasan dalam pemilihan anggota parlemen.

d. Bahwa hak setiap warga negara untuk memeluk agama menururt kepercayaannya.

Perjuangan untuk penegakan hak asasi manusia juga terjadi di Amerika Serikat yang diilhami oleh pemikiran John Locke (1632-1704) yang merumuskan hak-hak alam, seperti hak hidup, kebebasan dan hak milik (life, liberty and property). Pemikiran John Locke ini tampak dengan jelas dalam Declaration of Independence of the United States.

Melalui revolusi Amerika dengan Declaration of Independence-nya tanggal 4 Juli 1776, suatu deklarasi kemerdekaan yang diumumkan secara aklamasi oleh 13 negara bagian, merupakan pula piagam hak- hak asasi manusia karena mengandung pernyataan

"Bahwa sesungguhnya semua bangsa diciptakan sama derajat oleh Maha Pencipta. Bahwa semua manusia dianugerahi oleh Penciptanya hak hidup, kemerdekaan, dan kebebasan untuk menikmati kebahagiaan". Dengan Declaration of Independence di Amerika Serikat, menempatkan Amerika sebagai negara yang memberi perlindungan dan jaminan hak-hak asasi manusia dalam konstitusinya.

Selain di Inggris dan Amerika Serikat, di Prancis juga terjadi perjuangan untuk menegakkan hak asasi manusia dalam kehidupan berbangsa dan bernegara. Di negara Prancis hak asasi manusia dirumuskan dalam suatu naskah pada awal revolusi Prancis untuk melawan kesewenang-wenangan penguasa, naskah tersebut dikenal dengan nama Declaration des Droits de L'bomme et $d u$ Citoyen, yaitu suatu pernyataan mengenai hak-hak manusia dan warga negara. Dalam Declaration Des Droits De L'Homme Et Du Citoyen yang dicetuskan pada tahun 1789 ini mencanangkan hak atas 
kebebasan, kesamaan, dan persaudaraan atau kesetiakawanan (liberte, egalite dan fratenite). Kemudian di tahun 1791, semua hak-hak asasi manusia dicantumkan seluruhnya di dalam konstitusi Prancis yang kemudian ditambah dan diperluas lagi pada tahun 1793 dan 1848 serta dalam konstitusi tahun 1795. Banyak hak asasi manusia yang terkandung di dalam declaration ini, antara lain :

1. Bahwa manusia tidak boleh dituduh dan ditangkap selain menurut undang-undang.

2. Bahwa manusia merdeka berbuat sesuatu tanpa merugikan pihak lain.

3. Bahwa manusia dilahirkan merdeka dan tetap merdeka.

4. Bahwa manusia mempunyai hak yang sama.

5. Bahwa warga negara mempunyai hak dan kedudukan yang sama.6

Agar supaya hak asasi manusia ini dapat diberlakukan terhadap bangsabangsa di dunia, maka pada tahun 1946 yaitu setelah perang dunia kedua disusunlah rancangan piagam hak asasi manusia oleh organisasi kerjasama untuk social ekonomi Perserikatan

6

https:// bahaudinonline.blogspot.co.id/2012 /11/sejarah-perkembangan-ham-hakasasi.html
Bangsa Bangsa (selanjutnya disebut PBB) yang terdiri dari 18 negara anggota. Kemudian PBB membentuk Commission of Human Right yaitu sebuah komisi yang khusus mengenai hak asasi manusia yang mulai bersidang pada bulan Januari 1947. Kemudian pada tanggal 10 Desember 1948, sidang umum PBB yang diselenggarakan di Istana Chailot - Paris, menerima baik hasil-hasil kerja panitia tersebut berupa Universal Declaration of Human Rights yaitu Pernyataan Sedunia tentang Hak Hak Asasi Manusia. Declaration of Human Rights ini terdiri dari 30 pasal yang disetujui oleh 48 negara dari 58 negara yang hadir dalam sidang umum PBB tersebut. Diantara hak asasi manusia yang menarik yang akan dibahas lebih lanjut dalam tulisan ini adalah hak hidup, hak kemerdekaan dan keamanan badan serta hak memperoleh pengakuan yang sama dengan orang lain menurut hukum untuk mendapatkan jaminan hukum dalam perkara pidana, seperti diperiksa di muka umum, dianggap tidak bersalah kecuali ada bukti yang sah.

Pengaturan yang berkaitan dengan hak asasi manusia di Indonesia sesungguhnya sudah banyak, tersebar di berbagai macam peraturan perundang- 
undangan, mulai dari derajat yang paling tinggi yaitu Undang Undang dasar 1945 sampai pada peraturan yang lebih rendah derajat. Dalam Undang Undang Dasar 1945 pengaturan tentang Hak Asasi Manusia diatur mulai Pasal 28A sampai dengan Pasal 28J. Salah satu undang undang yang lebih spesifik mengatur tentang hak asasi manusia ialah Undang Undang Nomor 39 Tahun 1999 tentang Hak Asasi Manusia. Dalam ketentuan Pasal 3 ayat (2) Undang Undang Nomor 39 Tahun 1999 menyebutkan, bahwa "Setiap orang berhak atas pengakuan, jaminan, perlindungan dan perlakuan hukum yang adil serta mendapat kepastian hukum dan perlakuan yang sama di depan hukum"

Jika dilihat dalam perspektif hukum Hak Asasi Manusia, baik hukum Hak Asasi Manusia nasional maupun hukum Hak Asasi Manusia Internasional, maka dapatlah diperoleh suatu pemahaman bahwa penegakan hukum oleh negara yang tidak mampu memberikan suatu kepastian hukum, maka sesungguhnya sudah dapat dikatakan sebagai pelanggaran Hak Asasi Manusia atau setidak-tidaknya sangat berpotensi terhadap pelanggaran Hak Asasi Manusia.
Sebagaimana dimaklumi bahwa hak untuk hidup sesungguhnya merupakan suatu prinsip moral yang disandarkan kepada keyakinan bahwa hak untuk hidup itu bawaan setiap orang yang diberikan oleh Tuhan Yang Maha Esa yang tidak boleh dikurangi sedikitpun juga, bukan sebagai hak istimewa yang diberikan oleh pemangku kekuasaan politik. Kelayakan dan ketenteraman dalam melaksanakan hak hidup penting untuk dihormati dan bebas dari segala gangugan dari siapapun dan dalam bentuk apapun. Kebebasan dalam menjalankan hak untuk hidup didasarkan pada kemampuan untuk merencanakan dan mengantisipasi masa depan seseorang.

Penetapan status tersangka kepada seseorang sangat erat kaitannya dengan kelayakan dan ketenteraman hak hudup yang nyaman, karena bagaimanapun juga tekanan psikologis status tersangka dapat mempengaruhi pola perikehidupan seseorang. Dalam hal ini saya teringat sebuah kasus yang cikup menggelitik hati saya pada waktu itu, karena pada saat itu payung hukumnya belum ada, yaitu kasus permohonan praperadilan yang diajukan oleh Muspani pada tahun 2010, seorang mantan anggota Dewan Perwakilan 
Daerah (DPD) Bengkulu, kepada Pengadilan Negeri Jakarta Pusat dalam kasus penyimpangan anggaran senilai Rp 21,3 miliar yang disangkakan kepada Gubernur Bengkulu Agusrin M Najamudin pada waktu itu. Ketika itu Muspani merasa heran, karena kasus itu sesungguhnya sudah lama terungkap yaitu sekitar tahun 2006, akan tetapi Kejaksaan belum juga melimpahkan berkas perkaranya ke Pengadilan. Pada hal Agusrin M Najamudin sudah ditetapkan sebagai tersangka pada Agustus 2008 dan penyidikan sudah dinyatakan lengkap pada bulan Mei 2009. Bahkan ketika itu Muspani sempat menduga bahwa Kejaksaan telah menerbitkan Surat Keputusan Penghentian Penyidikan (SKPP) secara diam-diam, karena sekitar satu setengah tahun menyandang status tersangka, belum ada kejelasan kapan perkara tersebut akan dilimpahkan ke pengadilan.

Hakim tungggal Supraja yang mengadili permohonan praperadilan di Pengadilan Negeri Jakarta Pusat, dalam putusannya pada tanggal 4 Nopember 2010 mengabulkan permohonan praperadilan tersebut. Dalam amar putusannya, Supraja sebagai hakim tunggal yang mengadili perkara permohonan praperadilan tersebut memerintahkan kepada Kejaksaan untuk segera melimpahkan perkara atas nama tersangka Gubernur Bengkulu Agusrin M Najamudin. Paling tidak ada dua hal yang menarik dari putusan praperadilan ini, pertama ketidakjelasan proses penyidikan yang berlangsung selama bertahun-tahun yang dapat mengakibatkan ketidakpastian hukum, bukan merupakan objek praperadilan sebagaimana yang disebutkan dalam Pasal 77 huruf a KUHAP yang menyebutkan bahwa "Pengadilan Negeri berwenang untuk memeriksa dan memutus, sesuai dengan ketentuan yang diatur dalam undang undang ini tentang sah atau tidaknya penangkapan, penahanan, penghentian penyidikan atau penghentian penuntutan". Dalam perkara praperadilan ini ternyata proses penyidikan oleh Kejaksaan tetap berjalan, artinya tidak dihentikan, sehingga bukan menjadi objek praperadilan. Akan tetapi hakim tunggal Supraja perlu mendapat apresiasi, karena putusannya dengan tegas memerintahkan pihak Kejaksaan untuk dengan segera melimpahkan perkaranya ke Pengadilan. Hal ini tentu saja berkaitan erat dengan ketidak pastian lamanya status tersangka yang 
disandang oleh tersangka, yang pada akhirnya justru sangat berpotensi melanggar hak asasi manusia. Kedua, hakim tunggal Supraja tidak dengan tegas menyebutkan dalam putusannya mengenai tenggat waktu bagi Kejaksaan untuk melimpahkan perkara tersebut ke Pangadilan. Pada hal itu sangat penting untuk mengakhiri berlarut-larutnya perkara pada tingkat penyidikan dan juga berlarut-larutnya seseorang menyandang status tersangka yang sangat berpotensi melanggar hak asasi manusia. Pernahkah terpikirkan oleh aparat penegak hukum, khususnya kepolisian dan kejaksaan bahwa orang yang terlalu lama menyandang status tersangka dapat menderita gangguan kecemasan sosial. Yang dimaksud gangguan kecemasan soaial (fobia sosial) adalah sebuah kondisi kesehatan jiwa. Kondisi ini merupakan ketakutan yang kuat dan terus-menerus merasa diawasi dan dinilai oleh orang lain. Ketakutan semacam ini dapat mempengaruhi pekerjaan, sekolah, dan aktivitas harian lainnya. Kondisi ini bahkan dapat menyulitkan untuk membentuk dan menjaga pertemanan ${ }^{7}$

7 https:// wnw.cahayajiwa.com/gangguankecemasan-sosial-lebih-dari-sekadarrasa-malu.
Selain dapat menderita ganguan kecemasan sosial, terlalu lama menyandang status tersangka orang dapat juga menderita depresi, yaitu suatu kondisi yang lebih dari suatu keadaan sedih, bila kondisi depresi seseorang sampai menyebabkan terganggunya aktivitas sosial sehariharinya maka hal itu disebut sebagai suatu gangguan depresi mayor. Beberapa gejala gangguan depresi mayor adalah perasaan sedih, rasa lelah yang berlebihan setelah aktivitas rutin yang biasa, hilang minat dan semangat, malas beraktivitas, dan gangguan pola tidur. Depresi merupakan salah satu penyebab utama kejadian bunuh diri ${ }^{8}$

\section{Penutup}

Penetapan status tersangkan kepada seseorang yang diduga sebagai pelaku tindak pidana yang dilakukan oleh kepolisian berdasarkan kepada ketetuan yang diatur dalam Undang Undang Nomor 8 Tahun 1981 Tentang Hukum Acara Pidana. Dalam undang undang tersebut hanya mengatur syarat (yang dinilai multi interpretasi), yang

8 https://id.wikipedia.org/wiki/Depresi_(p sikologi)

DOI: http://dx.doi.org/10.18592/sy.v17i2.1972

http://jurnal.uin-antasari.ac.id/index.php/syariah/article/view/1972 
harus dipenuhi untuk menetapkan status tersangka kepada seseorang yang diduga sebagai pelakunya. Mahkamah Konstitusi dalam putusannya bernomor 21/PUU-XII/2014 memberikan interpretasi yang lebih konkret terhadap Pasal 1 angka 14, Pasal 17 dan Pasal 21 KUHAP yang pada pokoknya menyebutkan bahwa untuk menetapkan tersangka minimal harus dipenuhi dua alat bukti. Akan tetapi tidak ada mengatur batasan lamanya seseorang berstatus tersangka. Oleh karena tidak ada diatur batasan lama waktu seseorang berstatus tersangka, maka sangat berpotensi terjadinya pelanggaran HAM.

Dimasa yang akan datang perlu danya aturan yang membatasi lamanya seseorang berstatus tersangka, selain untuk menghendari potensi pelanggaran HAM, juga untuk memberikan kepastian hukum kepada masyarakat pencari keadilan.

\section{Daftar Pustaka}

Ali, Achmad. 2015. Menguak Realitas Hukum, Jakarta: Kencana (Prenada Media Grup) . 2015. Menguak Teori Hukum (legal Theory) dan Teori Peradilan (judicialprudence). Jakarta: Prenada Media Group. dan Wiwie Heryani. 2015. Kajian Empiris Hukum. Jakarta: Prenada Media.

Atmasasmita, Romli. 2014. Sistem Peradilan pidana Kontemporer. Jakarta :: Prenada Media Grup (Kencana

Lopa, Baharuddin. 1987. Permasalahan Pembinaan dan Penegakan bukum di Indonesia. Jakarta: Bulan Bintang. Mardjono, Hartono. 2001. Negara Hukum yang Demokratis sebagai Landasan Membangun Indonesia Baru. Jakarta: Koridor Pengabdian.

Manan, Bagir. 2005. Sistem Peradilan Berwibawa (Suatu Pencarian). Yogyakarta: FH UII Press.

Mustafa, Bachsan. 2003. Sistem Hukum Indonesia Terpadu. Bandung: PT. Citra Aditya Bakti.

Renggong, Ruslan. 2014. Hukum Acara Pidana. Jakarta: Prenada Media Group.

Radbruch, Gustav. 1961. Einfubrung in die Rechtswissenschaft. Stuttgart : K.F. Koehler.

Rawls, John. 1972. A. Theory of Justice. Cambridge Mass : Harvard University Press.

Rahardjo, Satjipto. 1983. Permasalahan Pembinaan dan Penegakan Hukum di Indonesia, Suatu Tinjauan Sosiologis. Bandung: Sinar Baru. 1986. Imu Hukum. Bandung: Alumni. 1986. Hukum dan Masyarakat. Cet. 4. Bandung: Angkasa. 1986. "Hukum dalam Perspektif Sejarah dan 
Perubahan Sosial" dalam

Pembangunan Hukum dalam

Perspektif Politik Hukum Nasional.

Jakarta: Rajawali.

Santoso, Agus.H.M. 2015. Hukum,

Moral \& Keadilan. Jakarta :

Prenada Media Group

Sofyan, Andi dan Abd. Asis. 2014.

Hukum Acara Pidana. Jakarta :

Prenada Media Group.

. 2014.Hukum Acara Pidana

Suatu Pengantar. Jakarta:

Prenada Media Group..

Soedjono, D. 1982. Pemeriksaan

Pendabuluan Menurut KUHAP.

Bandung : Alumni.

Soekanto, Soerjono. 1983. Penegakan

Hukum. Cet. 1 Bandung: Bina

Cipta.

. 1986. Pengantar Penelitian

Hukum. Jakarta: UI Press.

- 2005. Faktor-faktor yang

Mempengarubi Penegakan Hukum.

PT. Raja Grafindo Persada.

Soemitro. Hanitijo Ronny. 1984.

Permasalahan Hukum dalam

Masyarakat. Bandung: Alumni.

Sumbayak, FS. Radisman. 1995. Beberapa

Pemikiran Kearah Pemantapan

Penegakan Hukum. Cet. 1. Jakarta:

Indonesia-HILL. Co.

Syamsudin, M. 2015. Konstruksi Baru

Budaya Hukum Hakim : Berbasis

Hukum Progresif. Jakarta:

Kencana Prenada Media.

Wahjono, Padmo. 1982. Indonesia Negara

Berdasar Atas Hukum.Jakarta :

Ghalia Indonesia.

\section{Peraturan Perundang-undangan}

Undang Undang Dasar RI Tahun 1945.
Undang Undang Nomor 8 Tahun 1981 Tentang Hukum Acara Pidana.

Peraturan Pemerintah Nomor 27 Tahun 1983 Tentang Pelaksanaan Kitab Undang Undang Hukum Acara Pidana.

Peraturan Kapolri No. 14 Tahun 2012 tentang Manajemen Penyidikan Perkara Pidana. 